\title{
Determinan Kemiskinan Multidimensi Kabupaten/Kota di Kawasan Timur Indonesia Menggunakan Geographically Weighted Regression
}

\author{
Annisa Intan Setyani ${ }^{1, \text { a) }}$, Sugiarto ${ }^{1, \text { b) }}$ \\ ${ }^{1}$ Program Studi Diploma IV, Jurusan Statistika Sosial dan Kependudukan, Politeknik Statistika STIS, Jakarta \\ Email: ${ }^{\text {a) } 211709564 @ \text { stis.ac.id, }},{ }^{\text {b) }}$ soegie@stis.ac.id
}

\begin{abstract}
There is still inequality in the distribution of poverty between regions in Indonesia where most provinces in Eastern Indonesia have a higher Multidimensional Poverty Rate (MPR) than the Western Indonesia and the national rate. Several provinces in Eastern Indonesia even have a large gap between the multidimensional poverty rate and its monetary poverty rate. Eastern Indonesia provinces with high MPR tends to be close geographically. This study aims to analyze the variables affecting MPR in districts/cities in Eastern Indonesia by considering spatial effects. The analysis used in this research is inferential analysis using Geographically Weighted Regression $(G W R)$. The result showed that there were heteregeneity and spatial effects in the multidimensional poverty model in Eastern Indonesia. Dependency ratio, HDI, hospital-to-population ratio, percentage of villages with asphalt roads, and percentage of villages without internet signal have a different significant effect on the MPR for each district/city in Eastern Indonesia.
\end{abstract}

Keywords: multidimensional poverty, Eastern Indonesia, geographically weighted regression, heterogeneity, spatial.

\begin{abstract}
Abstrak
Masih terjadi ketidakmerataan kemiskinan antar wilayah di Indonesia dimana sebagian besar provinsi di Kawasan Timur Indonesia (KTI) memiliki nilai Angka Kemiskinan Multidimensi (AKM) yang lebih tinggi daripada Kawasan Barat Indonesia (KBI) dan angka nasional. Beberapa provinsi di KTI bahkan memiliki angka kemiskinan multidimensi dengan perbedaan nilai yang cukup jauh dibandingkan angka kemiskinan moneter wilayah tersebut. Wilayah KTI yang memiliki nilai AKM tinggi cenderung mengelompok secara geografis. Penelitian ini bertujuan untuk menganalisis variabel-variabel yang berpengaruh pada AKM kabupaten/kota di KTI dengan mempertimbangkan pengaruh spasial. Analisis yang digunakan dalam penelitian ini yaitu analisis inferensia dengan Geographically Weighted Regression (GWR). Hasil penelitian menunjukkan bahwa terdapat efek dan heteregenitas spasial pada pemodelan kemiskinan multidimensi di KTI. Rasio ketergantungan, IPM, rasio rumah sakit terhadap penduduk, persentase desa dengan dengan permukaan jalan mayoritas aspal, dan persentase desa tanpa sinyal internet memiliki pengaruh signifikan terhadap AKM yang berbeda-beda untuk setiap kabupaten/kota di KTI.
\end{abstract}

Kata-kata kunci: kemiskinan multidimensi, Kawasan Timur Indonesia, geographically weighted regression (GWR), heterogenitas, spasial. 


\section{PENDAHULUAN}

Kemiskinan merupakan persoalan yang selalu dipandang sebagai permasalahan utama di seluruh negara, baik di negara berkembang maupun negara maju. Kemiskinan sering kali diukur dengan pendekatan moneter saja yaitu menggunakan konsep basic needs approach atau kemampuan memenuhi kebutuhan dasar dari sisi ekonomi. Namun, pengukuran kemiskinan melalui pendekatan moneter hanya dapat memotret sebagian kecil dari luasnya persoalan kemiskinan (Prakarsa, 2020). Sen (2000) sudah lama menjelaskan bahwa kemiskinan mencakup aspek yang lebih luas seperti kebebasan dalam bidang ekonomi, sosial, politik, serta adanya keterbukaan dan keamanan. Terdapat beberapa kritik terhadap kemiskinan dengan pendekatan moneter, misalnya perhitungan kemiskinan moneter hanya mencakup sumber daya pribadi, dan menghilangkan pendapatan sosial yaitu berbagai barang dan jasa yang disediakan untuk umum seperti sekolah dan klinik. Hal ini dapat menyebabkan bias implisit dalam pemilihan kebijakan yang mendukung penciptaan pendapatan pribadi dibandingkan dengan penyediaan barang publik, serta bias dalam identifikasi orang miskin untuk tujuan penargetan terhadap mereka yang tidak memiliki pendapatan pribadi (Laderchi dan Stewart, 2003). Maka dari itu, diperlukan sebuah pendekatan yang mencakup berbagai dimensi yaitu melalui pendekatan multidimensi.

Indeks Kemiskinan Multidimensi (IKM) merupakan indeks komposit yang diharapkan mampu mencerminkan keadaan riil masyarakat miskin di Indonesia. Terdapat tiga aspek dalam IKM yaitu angka kemiskinan multidimensi, intensitas kemiskinan multidimensi, dan IKM itu sendiri. Angka kemiskinan multidimensi merupakan persentase jumlah penduduk miskin multidimensi atau penduduk yang terdeprivasi pada dimensi kesehatan, pendidikan,dan standar hidup yang layak terhadap total penduduk (Prakarsa, 2020).

Secara statistik, angka kemiskinan moneter di Indonesia sudah menunjukkan kecenderungan penurunan pada dua dekade terakhir dan mencapai angka 9,41\% pada Maret 2019. Namun, angka ini belum memenuhi target pembangunan nasional yang tercantum dalam Rencana Pembangunan Jangka Menengah (RPJMN) 2015-2019. Target persentase kemiskinan nasional tahun 2015-2019 dalam RPJMN adalah sebesar 7-8\% (Bappenas, 2014). Jika dibandingkan dengan angka kemiskinan multidimensi, angka kemiskinan moneter dan angka kemiskinan multidimensi pada tahun 2018 samasama sudah mengalami penurunan dibandingkan tahun-tahun sebelumnya. Angka kemiskinan multidimensi (AKM) mengalami penurunan yang lebih progresif dibandingkan angka kemiskinan moneter. Seperti pada tahun 2017, AKM nasional sudah berada di level satu digit, sebaliknya angka kemiskinan moneter masih berada di level dua digit. Namun, masih terdapat kesenjangan pada AKM di Indonesia.

Berdasarkan AKM 2018, sebagian besar provinsi di Kawasan Timur Indonesia (KTI) memiliki nilai AKM yang tinggi di atas angka nasional. Sebaliknya, AKM rendah didominasi oleh provinsiprovinsi di kawasan barat Indonesia (KBI). Selain itu, terdapat permasalahan kesenjangan antara angka kemiskinan multidimensi dan angka kemiskinan moneter di KTI. Rata-rata kesenjangan antara AKM dan angka kemiskinan moneter di KTI mencapai 8,21\%. Bahkan di Papua, kesenjangan antara AKM dan angka kemiskinan moneter mencapai angka 33.03\% dengan angka kemiskinan moneter bernilai $27,53 \%$ dan angka kemiskinan multidimensi mencapai $60.56 \%$ sehingga diperlukan perhatian lebih pada pengentasan kemiskinan dengan pendekatan multidimensi di KTI.

Provinsi-provinsi di KTI memiliki kondisi kemiskinan multidimensi yang berbeda-beda. Perbedaan tersebut menjadikan daerah tersebut memiliki karakteristiknya masing-masing sehingga fokus pengentasan kemiskinan tidak dapat disamaratakan untuk semua wilayah. Wilayah KTI yang memiliki AKM di atas AKM nasional cenderung berdekatan secara geografis. Hal ini mengindikasikan adanya pengaruh spasial pada kemiskinan multidimensi di KTI. Pemetaan data kemiskinan dengan mengintegrasikan data spasial dan data atribut dibutuhkan untuk inovasi penelitian maupun pengembangan kebijakan anti kemiskinan (Harmes et al., 2017). Hal ini sejalan dengan hukum pertama tentang geografi oleh Tobler (1979), "everything is related to everything else, but near things are more related than distant things" di mana dijelaskan bahwa segala sesuatu saling terkait satu sama lain, tetapi sesuatu yang lebih dekat akan lebih berpengaruh daripada sesuatu yang lebih jauh (Anselin, 1988). 
Penelitian mengenai faktor-faktor yang memengaruhi kemiskinan sudah beberapa kali dilakukan oleh para ahli. Salah satu penelitian mengenai determinan kemiskinan adalah penelitian yang dilakukan oleh Fardilla dan Masbar (2020) dengan menggunakan model fixed effect model (FEM). Hasil dari penelitian tersebut menemukan bahwa terdapat pengaruh signifikan positif oleh variabel listrik dan pengaruh negatif variabel infrastruktur jalan dan sekolah terhadap kemiskinan di Provinsi Aceh. Penelitian menggunakan analisis runtun waktu 13 tahun terkait pengaruh tenologi informasi dan komunikasi (TIK) terhadap laju kemiskinan di Indonesia dilakukan oleh Widiyastuti (2015). Penelitian tersebut dilakukan menggunakan variabel penetrasi telepon seluler, internet, dan pitalebar. Hasil penelitian menemukan bahwa TIK memiliki pengaruh yang signifikan terhadap laju penurunan kemiskinan yang didominasi oleh variabel tingkat penetrasi internet. Penelitian terkait determinan kemiskinan juga dilakukan oleh Andrietya et al. (2020) di Provinsi Jawa Tengah menggunakan pendekatan Fixed Model Effect (FEM). Hasil penelitian menunjukkan bahwa terdapat pengaruh signifikan negatif variabel indeks pembangunan manusia (IPM), PDRB, dan investasi terhadap kemiskinan di Jawa Tengah. Sebaliknya, variabel pengangguran dan dummy variabel mempunyai pengaruh negatif dan tidak signifikan terhadap kemiskinan di Jawa Tengah. Penelitian ini mengkaji kemiskinan multidimensi menggunakan metode yang mempertimbangkan aspek spasial yaitu geographically weighted regression (GWR) untuk menganalisis variabel-variabel apa saja yang berpengaruh terhadap AKM kabupaten/kota di KTI sehingga hasil yang diperoleh diharapkan dapat menjadi alternatif pemerintah dalam pengambilan kebijakan pengentasan kemiskinan.

\section{METODOLOGI}

\section{Bahan dan Data}

Penelitian ini menggunakan data sekunder cross section 232 kabupaten/kota di KTI tahun 2018 yang diperoleh dari beberapa publikasi yang dapat diakses secara online pada website Badan Pusat Statistik (BPS) dan Perkumpulan PRAKARSA. Variabel yang digunakan merupakan variabel terikat dan bebas pada level kabupaten/kota dengan rincian pada TABEL 1.

TABEL 1. Variabel dan skala pengukuran yang digunakan

\begin{tabular}{lcc}
\hline \multicolumn{1}{c}{ Variabel terikat } & $\begin{array}{c}\text { Skala } \\
\text { pengukuran }\end{array}$ & Sumber data \\
\hline AKM (\%) & Rasio & $\begin{array}{c}\text { Publikasi Indeks Kemiskinan } \\
\text { Multidimensi 2020 }\end{array}$ \\
\hline \multicolumn{1}{c}{ Variabel bebas } & $\begin{array}{c}\text { Skala } \\
\text { pengukuran }\end{array}$ & Sumber data \\
\hline $\begin{array}{l}\text { Rasio ketergantungan (\%) } \\
\text { Indeks Pembangunan Manusia (IPM) }\end{array}$ & Rasio & $\begin{array}{c}\text { Publikasi Provinsi dalam Angka 2019 } \\
\text { Publikasi Indeks Pembangunan }\end{array}$ \\
$\begin{array}{l}\text { Rasio rumah sakit terhadap penduduk (per } \\
\begin{array}{l}100.000 \text { jiwa) } \\
\text { Persentase desa dengan jalan mayoritas } \\
\text { aspal (\%) }\end{array}\end{array}$ & Rasio & Manusia 2018 \\
Persentase desa tanpa sinyal internet $(\%)$ & Rasio & Publikasi Provinsi dalam Angka 2019 \\
\end{tabular}

Angka kemiskinan multidimensi dinyatakan dalam bentuk persentase. Nilai prediksi AKM berada pada kisaran 0 sampai 100, sehingga perlu dilakukan transformasi nilai AKM agar hasil estimasi berada pada rentang tersebut. Transformasi yang dilakukan adalah sebagai berikut:

$$
Y_{i}=\ln \left[\frac{\mathrm{AKM} / 100}{1-\left({ }^{\mathrm{AKM} /} / 100\right)}\right] ; i=1,2, \ldots, n
$$

dimana $Y_{i}$ merupakan transformasi dari AKM dan i menunjukkan kabupaten/kota. 


\section{Metode Penelitian}

Berdasarkan tujuan penelitian, metode analisis yang digunakan dalam penelitian ini adalah analisis inferensia. Pengolahan data dalam penelitian ini menggunakan alat bantu antara lain software RStudio 3.6.1, QGIS 3.10.1, GeoDa 1.12.1.131, dan GWR4.

\section{Efek Spasial}

Konsep analisis data spasial terdiri dari dependensi spasial dan heterogenitas spasial (Anselin, 1988). Dependensi spasial menunjukkan suatu keadaan dimana nilai suatu variabel pada suatu lokasi dipengaruhi oleh nilai variabel tersebut di lokasi lain yang berdekatan. Sedangkan, heterogenitas spasial menunjukkan adanya ketidakstabilan struktural antar ruang dan perilaku hubungan antar variabel di berbagai wilayah.

Pengujian dependensi spasial atau autokorelasi spasial dilakukan melalui Indeks Moran atau Global Moran's I dengan rumus sebagai berikut:

$$
I=\frac{n \sum_{i} \sum_{j} w_{i j}\left(y_{i}-\bar{y}\right)\left(y_{j}-\bar{y}\right)}{W \sum_{i}\left(y_{i}-\bar{y}\right)^{2}} ; i=1,2, \ldots, n \text { dan } j=1,2, \ldots, n
$$

Nilai I akan berada pada rentang -1 sampai 1 . Nilai $-1 \leq$ I $<0$ menunjukkan adanya autokorelasi spasial negatif, sedangkan nilai $0<\mathrm{I} \leq 1$ menunjukkan adanya autokorelasi spasial positif.

Adapun pengujian Breusch-Pagan dilakukan menggunakan rumus,

$$
B P=\frac{1}{2} \mathbf{f}^{\prime} \mathbf{Z}\left(\mathbf{Z}^{\prime} \mathbf{Z}\right)^{-1} \mathbf{Z}^{\prime} \mathbf{f} \sim \chi_{(p)}^{2} \text { dimana } \mathrm{f}_{\mathrm{i}}=\left(\frac{\mathrm{e}_{\mathrm{i}}^{2}}{\mathrm{~s}^{2}}-1\right)
$$

$\mathbf{Z}$ adalah matriks berukuran $n \times(p+1)$ yang mengandung vektor amatan tiap observasi yang sudah dinormalstandarkan (dikurang rata-rata kemudian dibagi dengan simpangan baku), $\mathrm{e}_{\mathrm{i}}$ adalah residual observasi ke-i, dan $\sigma^{2}$ merupakan varians dari $\mathrm{e}_{\mathrm{i}}$.

\section{Geographically Weighted Regression (GWR)}

Metode GWR pertama kali diperkenalkan oleh Fotheringham pada tahun 1967 dan merupakan pengembangan dari metode regresi global. Konsep dalam pemodelan GWR adalah memperkirakan nilai parameter pada setiap titik lokasi pengamatan sehingga setiap titik pengamatan memiliki nilai parameter yang berbeda. Model GWR dapat dituliskan sebagai berikut (Fotheringham, Brundson, dan Charlton, 2002):

$$
\mathrm{y}_{\mathrm{i}}=\beta_{0}\left(\mathrm{u}_{\mathrm{i}}, \mathrm{v}_{\mathrm{i}}\right)+\sum_{\mathrm{k}=1}^{\mathrm{p}} \beta_{\mathrm{k}}\left(\mathrm{u}_{\mathrm{i}}, \mathrm{v}_{\mathrm{i}}\right) \mathrm{X}_{\mathrm{ik}}+\varepsilon_{\mathrm{i}}
$$

dimana $\mathrm{y}_{\mathrm{i}}$ merupakan nilai variabel respon pada titik lokasi pengamatan ke-i, $\left(\mathrm{u}_{\mathrm{i}}, \mathrm{v}_{\mathrm{i}}\right)$ adalah koordinat titik lokasi pengamatan ke-i, $\beta_{0}$ merupakan konstanta GWR, $\beta_{\mathrm{k}}$ merupakan koefisien regresi ke-k pada titik lokasi pengamatan $\mathrm{ke}-\mathrm{i}, \quad \mathrm{X}_{\mathrm{ik}}$ adalah nilai variabel prediktor ke- $k$ pada titik lokasi pengamatan ke $-\mathrm{i}$, dan $\varepsilon_{\mathrm{i}}$ merupakan error pada titik lokasi ke-I yang diasumsikan independen, identik, dan berdistribusi normal dengan rata-rata nol dan varians $\sigma^{2}$.

\section{Tahapan Analisis}

Tahapan analisis yang dilakukan untuk melihat pengaruh variabel bebas terhadap kemiskinan multidimensi antara lain sebagai berikut: 
1. Membentuk model OLS

2. Menguji asumsi klasik dan keberagaman spasial menggunakan uji Breusch-Pagan dengan hipotesis sebagai berikut:

$\mathrm{H}_{0}: \sigma_{1}^{2}=\sigma_{2}^{2}=\ldots=\sigma_{n}^{2}=\sigma^{2}$ (tidak terdapat heterogenitas antar wilayah)

$\mathrm{H}_{1}$ : minimal terdapat satu $\sigma_{i}^{2} \neq \sigma^{2}$ dengan $i=1,2, \ldots, n$ (terdapat heterogenitas antar wilayah)

Keputusan akan tolak $\mathrm{H}_{0}$ jika p-value $<0.05$ atau jika BP $>\chi_{(p)}^{2}$

3. Menguji efek ketergantungan spasial menggunakan Moran's I

4. Memilih bandwidth optimum dan fungsi pembobot spasial dengan menggunakan kriteria AICc dengan rumus sebagai berikut:

$$
\mathrm{AICc}=2 n \log _{\mathrm{e}}(\hat{\sigma})+\operatorname{nlog}_{\mathrm{e}}(2 \pi)+\mathrm{n}\left\{\frac{\mathrm{n}+\operatorname{tr}(\mathbf{S})}{\mathrm{n}-2-\operatorname{tr}(\mathbf{S})}\right\}
$$

5. Membentuk model GWR sebagai berikut:

$$
\begin{aligned}
& Y_{i}= \beta_{0}+\beta_{1}\left(u_{i}, v_{i}\right) \text { dep_ratio }{ }_{i}+\beta_{2}\left(u_{i}, v_{i}\right) \text { ipm }_{i}+\beta_{3}\left(u_{i}, v_{i}\right) \text { rasio_rs }_{i}+ \\
& \beta_{4}\left(u_{i}, v_{i}\right) \text { persen_aspal } \\
& i
\end{aligned}
$$

dimana $\left(\mathrm{u}_{\mathrm{i}}, \mathrm{v}_{\mathrm{i}}\right)$ merupakan titik koordinat kabupaten/kota ke-i, $\mathrm{Y}_{\mathrm{i}}$ merupakan transformasi angka kemiskinan multidimensi di kabupaten/kota ke-i,dep_ratio ${ }_{i}$ merupakan rasio ketergantungan di kabupaten/kota ke-i, ipm $_{\mathrm{i}}$ merupakan indeks pembangunan manusia di kabupaten/kota ke-i, rasio_rs ${ }_{i}$ merupakan rasio rumah sakit per 100.000 penduduk di kabupaten/kota ke-i, persen_aspal ${ }_{\mathrm{i}}$ merupakan persentase desa dengan dengan mayoritas jalan aspal di kabupaten/kota ke-i, dan tanpa_inet ${ }_{i}$ merupakan persentase desa tanpa sinyal internet di kabupaten/kota ke-i.

6. Mengidentifikasi variabel-variabel yang berpengaruh signifikan terhadap kemiskinan multidimensi pada masing-masing kabupaten/kota di KTI

\section{HASIL DAN PEMBAHASAN}

Untuk menganalisis pengaruh variabel rasio ketergantungan, IPM, rasio rumah sakit terhadap penduduk, persentase desa dengan jalan mayoritas aspal, dan persentase desa tanpa sinyal internet terhadap angka kemiskinan multidimensi, dilakukan analisis spasial menggunakan geographically weighted regression (GWR). Adapun prosedur dalam analisis GWR antara lain pembentukan model OLS, pemeriksaan asumsi klasik, pemeriksaan efek ketergantungan spasial, pembentukan model GWR, serta pengujian hipotesis model GWR.

Adapun langkah pertama yang dilakukan adalah pemodelan dengan menggunakan Ordinary Least Square (OLS) untuk melihat variabel mana saja yang memengaruhi AKM di KTI secara global. Model OLS dibentuk dengan meregresikan AKM yang sudah ditransformasi menggunakan persamaan (1) dengan kelima variabel bebas. Ringkasan model OLS yang terbentuk dapat dilihat pada TABEL 2. Berdasarkan ringkasan model yang diperoleh, terdapat empat variabel yang berpengaruh secara signifikan terhadap AKM di KTI tahun 2018 dengan tingkat signifikansi 5 persen. Variabel tersebut antara lain rasio ketergantungan, rasio rumah sakit terhadap penduduk, persentase desa dengan jalan mayoritas aspal, dan persentase desa tanpa sinyal internet. Variabel IPM tidak berpengaruh secara signifikan terhadap kemiskinan multidimensi di KTI. Adapun nilai $R$-squared pada model ini sebesar 0.3222 , yang berarti kelima variabel independen dapat menjelaskan sebesar 32.22 persen dari variasi AKM secara global.

TABEL 2. Estimasi parameter model regresi OLS

Variabel Coefficient Std.Error t-Statistic Probabilitas




\begin{tabular}{lcccc} 
Intersep & -4.777 & 0.866 & -5.517 & 0.000 \\
Rasio ketergantungan & 0.041 & 0.007 & 5.888 & 0.000 \\
IPM & 0.019 & 0.012 & 1.532 & 0.127 \\
Rasio rumah sakit terhadap penduduk & -0.222 & 0.071 & -3.130 & 0.002 \\
Persentase desa dengan jalan mayoritas aspal & -0.009 & 0.003 & -2.790 & 0.006 \\
Persentase desa tanpa sinyal internet & 0.019 & 0.005 & 4.020 & 0.000 \\
\hline
\end{tabular}

Selanjutnya dilakukan pengujian asumsi klasik antara lain asumsi normalitas, homoskedastisitas, non multikolinearitas, dan non autokorelasi. Hasil pengujian asumsi normalitas dengan statistik Kolmogorov Smirnov menghasilkan p-value yang lebih besar dari tingkat signifikansi 0.05 yaitu sebesar 0.2181 sehingga dapat disimpulkan bahwa asumsi normalitas residual pada model sudah terpenuhi. Pengujian asumsi nonautokorelasi menghasilkan nilai Durbin Watson sebesar 0.821. Nilai tersebut berada pada wilayah $0<\mathrm{DWp}<\mathrm{DL}$ yang berarti terdapat pelanggaran asumsi nonautokorelasi pada model OLS tersebut yaitu terjadi autokorelasi positif. Adapun pengujian asumsi nonmultikolinearitas menghasilkan nilai variance inflation factor (VIF) seluruh variabel kurang dari 10 sehingga dapat disimpulkan bahwa tidak terjadi multikolinearitas antar variabel bebas pada model. Selanjutnya, hasil uji Breusch Pagan dengan persamaan (3) menghasilkan p-value sebesar 0.000 yang bernilai lebih kecil dari tingkat signifikansi 0.05 sehingga dapat disimpulkan bahwa terdapat pelanggaran asumsi homoskedastisitas pada model OLS. Pelanggaran asumsi ini menujukkan bahwa varians error pada model tidak indentik sehingga perlu dilakukan analisis yang mempertimbangkan aspek kewilayahan.

Berdasarkan hasil pengujian asumsi klasik, terjadi pelanggaran dua asumsi klasik antara lain terjadinya heteroskedastisitas dan autokorelasi. Hal ini menunjukkan bahwa analisis dengan menggunakan model OLS sudah tidak tepat lagi untuk digunakan. Pelanggaran asumsi homoskedastisitas mengindikasikan adanya keberagaman spasial sehingga dibutuhkan pengujian efek spasial pada model.

Salah satu cara untuk melihat adanya efek ketergantungan spasial antar wilayah atau autokorelasi spasial adalah melalui Moran's $I$ yang dihitung menggunakan persamaan (2). TABEL 3 memperlihatkan hasil pengujian Moran's I dengan membandingkan tiga jenis matriks pembobot untuk menentukan matriks pembobot mana yang paling cocok untuk digunakan.

\begin{tabular}{ccc} 
TABEL 3. Perbandingan matriks pembobot autokorelasi spasial \\
\hline Matriks pembobot & Indeks Moran & p-value \\
\hline 2-Nearest Neighbors & 0.44367 & 0.0000 \\
3-Nearest Neighbors & 0.469546 & 0.0000 \\
Queen & 0.435984 & 0.0000 \\
\hline
\end{tabular}

Hasil pengujian menunjukkan bahwa terdapat cukup bukti untuk menyatakan adanya karakteristik AKM yang berbeda-beda antar unit observasi pada ketiga jenis matriks pembobot spasial. Pemilihan matriks pembobot kriteria jarak nearest neighbour dilakukan berdasarkan pertimbangan bahwa banyak wilayah di KTI yang dipisahkan oleh lautan sehingga tidak terjadi persinggungan wilayah.

Pengujian asumsi klasik dan efek ketergantungan spasial memperlihatkan bahwa terdapat perbedaan karakteristik antar wilayah observasi, sedangkan model OLS hanya menghasilkan estimasi yang bersifat global. Oleh karena itu, diperlukan sebuah model yang dapat mempertimbangkan efek spasial dan keberagaman tersebut salah satunya dengan menggunakan Geographically Weighted Regression (GWR) dengan persamaan (4) yang menghasilkan parameter yang bersifat lokal untuk setiap wilayah observasi.

Pemilihan bandwidth optimum dan fungsi pembobot merupakan tahap awal dalam permodelan GWR. Proses pemilihan bandwidth dan fungsi pembobot untuk menentukan model GWR terbaik dilakukan dengan meminimumkan nilai AICc yang dihitung dengan persamaan (5) menggunakan 
iterasi metode Golden Section Search. Pemilihan fungsi adaptive dilakukan karena wilayah KTI terdiri dari kepulauan sehingga centroid kabupaten/kota di KTI menyebar secara tidak merata.

TABEL 4. Perbandingan fungsi pembobot adaptive Gaussian dan bi-square

\begin{tabular}{cccccc}
\hline Fungsi Pembobot & $\begin{array}{c}\text { Bandwidth } \\
\text { Optimum }\end{array}$ & AICc & $\begin{array}{c}\text { R- } \\
\text { squared }\end{array}$ & $\begin{array}{c}\text { Adj. R- } \\
\text { squared }\end{array}$ & RSS \\
\hline adaptive Gaussian & 18 & 575.99 & 0.6463 & 0.5360 & 103.683 \\
adaptive Bisquare & 147 & 586.46 & 0.5308 & 0.4682 & 137.554 \\
\hline
\end{tabular}

Berdasarkan hasil perbandingan kedua fungsi pembobot pada TABEL 4, dapat disimpulkan bahwa fungsi adaptive Gaussian dengan bandwidth optimum sebesar 18 merupakan fungsi pembobot yang paling sesuai karena memiliki nilai AICc dan residual sum of square yang lebih kecil serta memiliki nilai R-squared dan adjusted R-squared yang lebih besar. Adapun bandwidth optimum yang diperoleh sebesar 18 menumjukkan bahwa terdapat 18 kabupaten/kota terdekat yang memiliki pengaruh signifikan terhadap estimasi suatu kabupaten/kota. Oleh karena itu, setelah matriks pembobot yang paling sesuai diperoleh, pemodelan GWR selanjutnya akan menggunakan matriks pembobot dengan fungsi pembobot adaptive Gaussian.

Setelah model dengan persamaan (6) terbentuk, selanjutnya dilakukan pengujian goodness of fit untuk melihat apakah model GWR yang terbentuk lebih baik untuk digunakan dibandingkan dengan model OLS. Hasil pengujian goodness of fit pada TABEL 5 menujukkan nilai $\mathrm{F}_{\text {hitung }}$ sebesar 3.44566 yang bernilai lebih besar dari $\mathrm{F}_{0.05(48.93 ; 177.07)}$ atau 1.4262. Hal ini menunjukan hasil tolak $\mathrm{H}_{0}$ dimana hubungan antar variabel lebih baik dijelaskan pada model GWR sehingga dapat disimpulkan bahwa model GWR lebih cocok untuk digunakan dibandingkan model OLS untuk menganalisis kemiskinan multidimensi di KTI.

TABEL 5. Tabel ANOVA GWR

\begin{tabular}{crrrr}
\hline Source & \multicolumn{1}{c}{ SS } & \multicolumn{1}{c}{ DF } & \multicolumn{1}{c}{ MS } & F \\
\hline Global Residuals & 198.728 & 226 & & \\
GWR Improvement & 95.046 & 48.933 & 1.942 & \\
GWR Residuals & 103.682 & 177.067 & 0.586 & 3.317131 \\
\hline
\end{tabular}

Selanjutnya dilakukam pengujian variasi masing-masing parameter model GWR untuk melihat apakah koefisien regresi bersifat lokal untuk masing-masing kabupaten/kota di KTI. Berdasarkan nilai difference of criterion pada TABEL 6, variabel rasio rumah sakit terhadap penduduk dan persentase desa tanpa sinyal internet memiliki difference of criterion yang bernilai positif. Hal ini menunjukkan bahwa variabel rasio ketergantungan, IPM, dan persentase desa dengan jalan mayoritas aspal memiliki pengaruh yang beragam secara kewilayahan, sedangkan variabel rasio rumah sakit terhadap penduduk dan persentase desa tanpa sinyal internet memiliki pengaruh yang bersifat global pada kemiskinan multidimensi kabupaten/kota di KTI.

TABEL 6. Pengujian variasi koefisien lokal

\begin{tabular}{lr}
\multicolumn{2}{c}{ TABEL 6. Pengujian variasi koefisien lokal } \\
\hline Variabel & difference of criterion \\
\hline Intercept & -1691.609431 \\
IPM & -376.536587 \\
Rasio ketergantungan & -121.028533 \\
Rasio rumah sakit terhadap penduduk & 1.805089 \\
Persentase desa dengan jalan mayoritas aspal & -39.36641 \\
Persentase desa tanpa sinyal internet & 8.130911 \\
\hline
\end{tabular}

Pemodelan dengan model GWR dapat menghasilkan signifikansi variabel yang berbeda-beda antar wilayah satu dengan wilayah lainnya. Pengujian parsial parameter GWR dilakukan untuk melihat variabel bebas mana saja yang memengaruhi AKM secara signifikan pada setiap kabupaten/kota di KTI. Ringkasan pengujian parsial parameter GWR dapat dilihat pada TABEL 7. 
TABEL 7. Variabel yang siginifikan memengaruhi AKM di KTI

\begin{tabular}{lc}
\hline \multicolumn{1}{c}{ Variabel } & Jumlah kabupaten/kota yang signifikan \\
\hline Rasio ketergantungan & 89 \\
IPM & 73 \\
Rasio rumah sakit terhadap penduduk & 48 \\
Persentase desa dengan jalan mayoritas aspal & 107 \\
Persentase desa tanpa sinyal internet & 133 \\
\hline
\end{tabular}

Apabila melihat ringkasan hasil pengujian parsial parameter GWR, diperoleh bahwa variabel persentase desa tanpa sinyal internet paling banyak memengaruhi AKM di kabupaten/kota di KTI yaitu sebanyak 133 kabupaten/kota. Sebaliknya, rasio rumah sakit terhadap penduduk memiliki pengaruh signifikan secara parsial paling sedikit terhadap kemiskinan multidimensi kabupaten/kota di KTI. Adapun analisis dengan GWR menghasilkan persamaan regresi pada setiap kabupaten/kota, sehingga terdapat 232 persamaan regresi yang diperoleh. Pengelompokkan kabupaten/kota beserta variabel-variabel yang signifikan memengaruhi AKM di kabupaten/kota di KTI dapat dilihat pada TABEL 8.

TABEL 8. Variabel yang siginifikan memengaruhi AKM di KTI

\begin{tabular}{|c|c|c|}
\hline No & Kabupaten/Kota & Variabel yang signifikan \\
\hline 1 & Bone Bolango & Tidak ada yang signifikan \\
\hline 2 & Lembata, Flores Timur, Konawe, Kota Kendari & Rasio ketergantungan \\
\hline 3 & Wakatobi, Konawe Kepulauan & Rasio ketergantungan, IPM \\
\hline 4 & $\begin{array}{l}\text { Timor Tengah Selatan, Timor Tengah Utara, Belu, Alor, Malaka, Maluku Barat } \\
\text { Daya, Tana Tidung, Nunukan, Kota Tarakan }\end{array}$ & $\begin{array}{l}\text { Rasio ketergantungan, IPM, \% } \\
\text { desa dengan jalan mayoritas } \\
\text { aspal }\end{array}$ \\
\hline 5 & Buru, Buru Selatan & $\begin{array}{l}\text { Rasio ketergantungan, IPM, \% } \\
\text { desa dengan jalan mayoritas } \\
\text { aspal, \% desa tanpa sinyal } \\
\text { internet }\end{array}$ \\
\hline
\end{tabular}

6 Morowali, Banggai Laut, Luwu Timur, Buton, Buton Utara, Konawe Utara, Buton Selatan, Kepulauan Sula, Pulau Taliabu

$7 \quad$ Maluku Tenggara Barat

8 Lombok Barat, Kupang, Sikka, Rote Ndao, Sabu Raijua, Kota Kupang

9 Lombok Tengah, Lombok Timur, Sumbawa, Dompu, Bima, Sumbawa Barat, Lombok Utara, Kota Mataram, Kota Bima, Sumba Barat, Sumba Timur, Ende, Ngada, Manggarai, Manggarai Barat, Sumba Tengah, Sumba Barat Daya, Nagekeo, Manggarai Timur, Seram Bagian Barat, Kota Ambon

10 Kepulauan Selayar, Bulukumba, Bantaeng, Jeneponto, Takalar, Gowa, Sinjai, Maros, Pangkajene Dan Kepulauan, Barru, Bone, Soppeng, Wajo, Sidenreng Rappang, Pinrang, Enrekang, Luwu, Tana Toraja, Toraja Utara, Kota Makassar, Kota Pare-Pare, Kota Palopo, Muna, Kolaka, Konawe Selatan, Bombana, Kolaka Utara, Kolaka Timur, Muna Barat, Buton Tengah, Kota Bau-Bau, Majene, Polewali Mandar, Mamasa, Mamuju

11 Bolaang Mongondow Utara, Donggala, Toli-Toli, Buol, Parigi Moutong, Tojo Una-Una, Morowali Utara, Kota Palu, Boalemo, Gorontalo, Pohuwato, Gorontalo Utara, Kota Gorontalo
Rasio ketergantungan, IPM, \% desa tanpa sinyal internet

Rasio ketergantungan, Rasio rumah sakit terhadap penduduk, $\%$ desa dengan jalan mayoritas aspal, \% desa tanpa sinyal internet

Rasio ketergantungan, \% desa dengan jalan mayoritas aspal

Rasio ketergantungan, \% desa dengan jalan mayoritas aspal, $\%$ desa tanpa sinyal internet

Rasio ketergantungan, \% desa tanpa sinyal internet 
TABEL 8. Variabel yang siginifikan memengaruhi AKM di KTI

\begin{tabular}{|c|c|c|}
\hline No & Kabupaten/Kota & Variabel yang signifikan \\
\hline 12 & $\begin{array}{l}\text { Tanah Laut, Kota Baru, Hulu Sungai Tengah, Tanah Bumbu, Balangan, Paser, } \\
\text { Kutai Barat, Kutai Kartanegara, Kutai Timur, Berau, Penajam Paser Utara, } \\
\text { Mahakam Ulu, Kota Balikpapan, Kota Samarinda, Kota Bontang, Malinau, } \\
\text { Bulungan }\end{array}$ & $\begin{array}{l}\text { IPM, \% desa dengan jalan } \\
\text { mayoritas aspal }\end{array}$ \\
\hline 13 & $\begin{array}{l}\text { Kepulauan Sangihe, Kepulauan Talaud, Halmahera Selatan, Kota Ternate, Kota } \\
\text { Tidore Kepulauan }\end{array}$ & $\begin{array}{l}\text { IPM, \% desa dengan jalan } \\
\text { mayoritas aspal, \% desa tanpa } \\
\text { sinyal internet }\end{array}$ \\
\hline 14 & $\begin{array}{l}\text { Bolaang Mongondow, Minahasa, Minahasa Selatan, Minahasa Utara, Minahasa } \\
\text { Tenggara, Bolaang Mongondow Selatan, Bolaang Mongondow Timur, Kota } \\
\text { Manado, Kota Tomohon, Kota Kotamobagu, Banggai Kepulauan, Banggai, Poso, } \\
\text { Sigi, Mamuju Utara, Mamuju Tengah }\end{array}$ & IPM, \% desa tanpa sinyal internet \\
\hline 15 & $\begin{array}{l}\text { Jayawijaya, Puncak Jaya, Boven Digoel, Asmat, Yahukimo, Pegunungan Bintang, } \\
\text { Tolikara, Nduga, Lanny Jaya, Yalimo, Puncak }\end{array}$ & $\begin{array}{l}\text { Rasio rumah sakit terhadap } \\
\text { penduduk }\end{array}$ \\
\hline 16 & Maluku Tengah, Seram Bagian Timur, Sorong, Raja Ampat & $\begin{array}{l}\text { Rasio rumah sakit terhadap } \\
\text { penduduk, \% desa dengan jalan } \\
\text { mayoritas aspal, \% desa tanpa } \\
\text { sinyal internet }\end{array}$ \\
\hline 17 & $\begin{array}{l}\text { Maluku Tenggara, Kepulauan Aru, Kota Tual, Fakfak, Kaimana, Teluk Wondama, } \\
\text { Teluk Bintuni, Manokwari, Sorong Selatan, Tambrauw, Maybrat, Manokwari } \\
\text { Selatan, Pegunungan Arfak, Kota Sorong, Merauke, Jayapura, Nabire, Kepulauan } \\
\text { Yapen, Biak Numfor, Paniai, Mimika, Mappi, Sarmi, Keerom, Waropen, Supiori, } \\
\text { Mamberamo Raya, Mamberamo Tengah, Dogiyai, Intan Jaya, Deiyai, Kota } \\
\text { Jayapura }\end{array}$ & $\begin{array}{l}\text { Rasio rumah sakit terhadap } \\
\text { penduduk, \% desa tanpa sinyal } \\
\text { internet }\end{array}$ \\
\hline 18 & $\begin{array}{l}\text { Sambas, Bengkayang, Landak, Mempawah, Sanggau, Ketapang, Sintang, Kapuas } \\
\text { Hulu, Sekadau, Melawi, Kayong Utara, Kubu Raya, Kota Pontianak, Kota } \\
\text { Singkawang, Kotawaringin Barat, Kotawaringin Timur, Kapuas, Barito Selatan, } \\
\text { Barito Utara, Sukamara, Lamandau, Seruyan, Katingan, Pulang Pisau, Gunung } \\
\text { Mas, Barito Timur, Murung Raya, Kota Palangka Raya, Banjar, Barito Kuala, } \\
\text { Tapin, Hulu Sungai Selatan, Hulu Sungai Utara, Tabalong, Kota Banjarmasin, } \\
\text { Kota Banjar Baru }\end{array}$ & $\begin{array}{l}\% \text { desa dengan jalan mayoritas } \\
\text { aspal }\end{array}$ \\
\hline 19 & $\begin{array}{l}\text { Siau Tagulandang Biaro, Halmahera Barat, Halmahera Tengah, Halmahera Utara, } \\
\text { Halmahera Timur, Pulau Morotai }\end{array}$ & $\begin{array}{l}\% \text { desa dengan jalan mayoritas } \\
\text { aspal, } \% \text { desa tanpa sinyal } \\
\text { internet }\end{array}$ \\
\hline 20 & Kota Bitung, Luwu Utara & $\%$ desa tanpa sinyal internet \\
\hline
\end{tabular}

TABEL 8 memperlihatkan terdapat 20 pengelompokan kabupaten/kota yang diperoleh berdasarkan signifikansi variabel yang sama. Hal ini menunjukkan bahwa dalam upaya menurunkan kemiskinan multidimensi di KTI diperlukan pertimbangan yang berbeda antar wilayah berdasarkan aspek yang berpengaruh di wilayah tersebut. Sebanyak dua kelompok memiliki empat variabel yang berpengaruh signifikan, yaitu kelompok 5 dan 7. Kelompok 5 beranggotakan Kabupaten Buru dan Buru Selatan, sedangkan kelompok 7 beranggotakan Kabupaten Maluku Tenggara Barat. Hal ini menunjukkan bahwa ketiga daerah tersebut memerlukan perhatian lebih dalam pengentasan kemiskinan multidimensinya. Selain itu, kelompok 1 yang hanya beranggotakan Kabupaten Bone Bolango tidak memiliki variabel bebas yang signifikan memengaruhi AKM. Hal tersebut dapat terjadi karena Kabupaten Bone Bolango sudah memiliki AKM yang rendah atau terdapat pengaruh oleh variabel lain di luar model. 


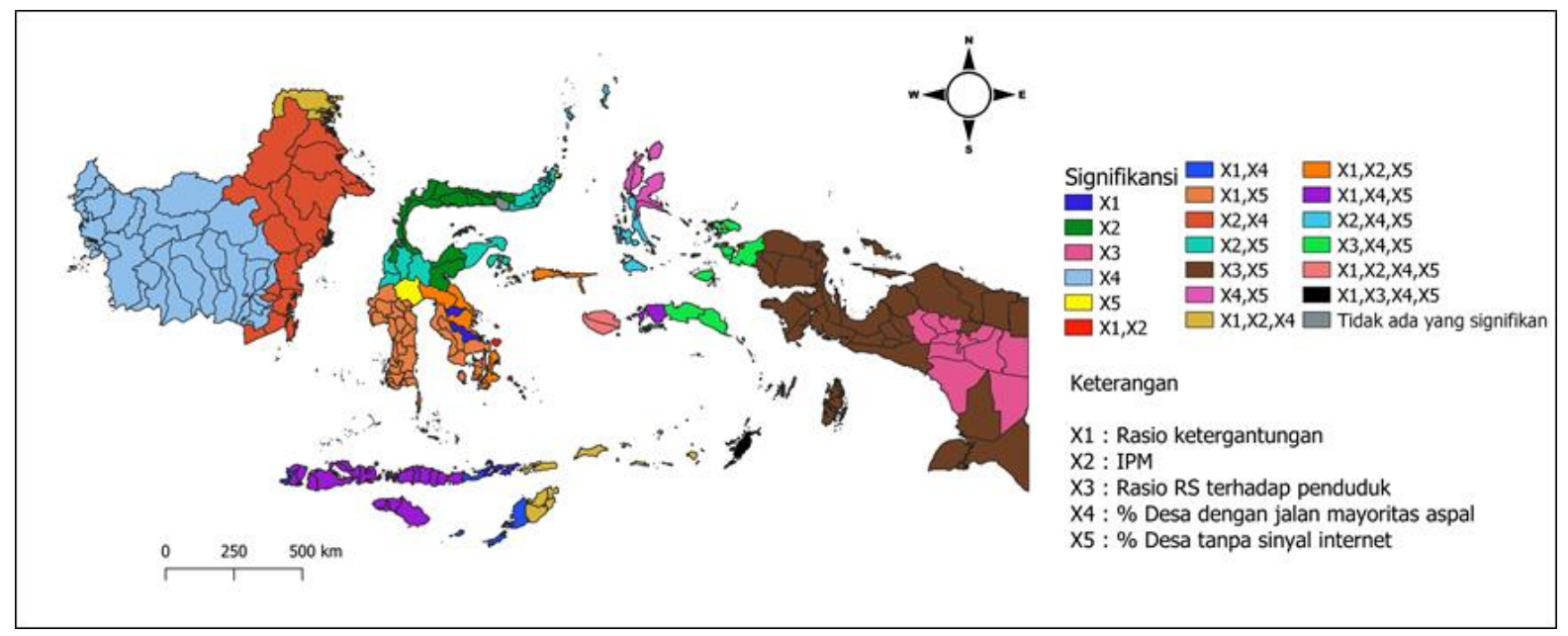

GAMBAR 1. Peta signifikansi variabel-variabel yang memengaruhi AKM

Untuk melihat sebaran kelompok signifikansi variabel secara visual, kabupaten/kota dengan variabel-variabel signifikan yang sama kemudian dikelompokan berdasarkan warna dalam bentuk peta tematik pada GAMBAR 1. Daerah yang memiliki kesamaan pada variabel memengaruhi kemiskinan multidimensi cenderung berdekatan dan mengelompok. Hal ini menandakan bahwa kebijakan terkait pengentasan kemiskinan multidimensi suatu wilayah di KTI dapat memengaruhi wilayah lain yang berdekatan.

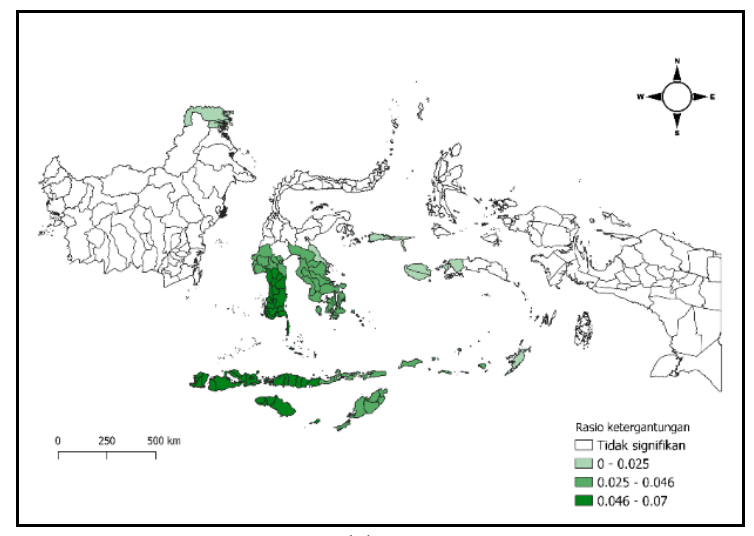

(a)

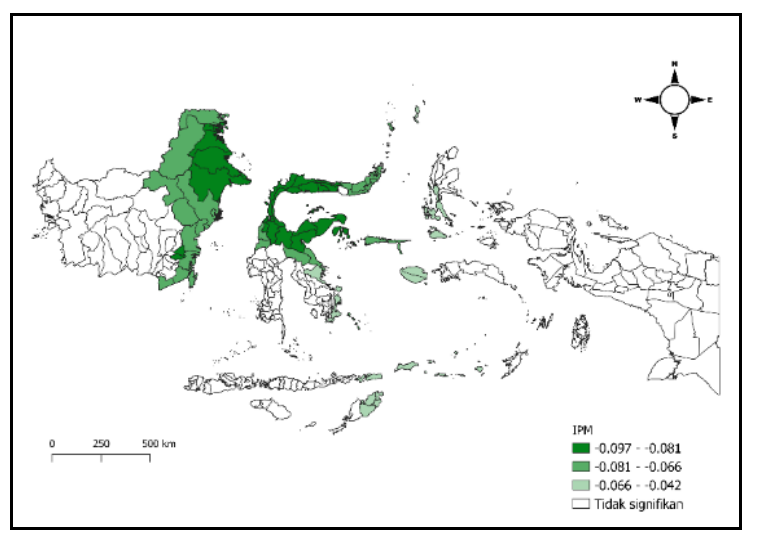

(b)

GAMBAR 2. Estimasi koefisien variabel lokal: (a) rasio ketergantungan (b) IPM

Apabila ditinjau berdasarkan estimasi masing-masing variabel, GAMBAR 2a memperlihatkan bahwa terdapat 89 kabupaten/kota di KTI yang signifikan dipengaruhi oleh rasio ketergantungan. Secara umum, wilayah dengan pengaruh signifikan positif variabel rasio ketergantungan tersebar di beberapa wilayah bagian barat KTI seperti Provinsi Nusa Tenggara Barat, dan beberapa kabupaten/kota di Nusa Tenggara Timur dan Sulawesi Selatan. Pengaruh tersebut sejalan dengan penelitian oleh Vijayakumar (2013) yaitu rasio ketergantungan yang tinggi dalam sebuah keluarga, terutama pada negara berkembang, menyebabkan produktivitas yang lebih rendah. Ketersediaan makanan bergizi, kesehatan, dan pendidikan yang kurang memadai karena produktivitas yang rendah akan menyebabkan kemiskinan multidimensi.

Sementara variabel IPM pada GAMBAR $2 \mathrm{~b}$ berpengaruh signifikan pada 73 kabupaten/kota. IPM signifikan negatif memengaruhi AKM pada kabupaten/kota di Pulau Sulawesi bagian utara serta Kalimantan bagian timur. Pengaruh tersebut sejalan dengan penelitian oleh Sayifullah dan Gandasari (2015) yang menemukan bahwa kualitas sumber daya manusia yang baik akan meningkatkan kesejahteraan dan menurunkan kemiskinan. 


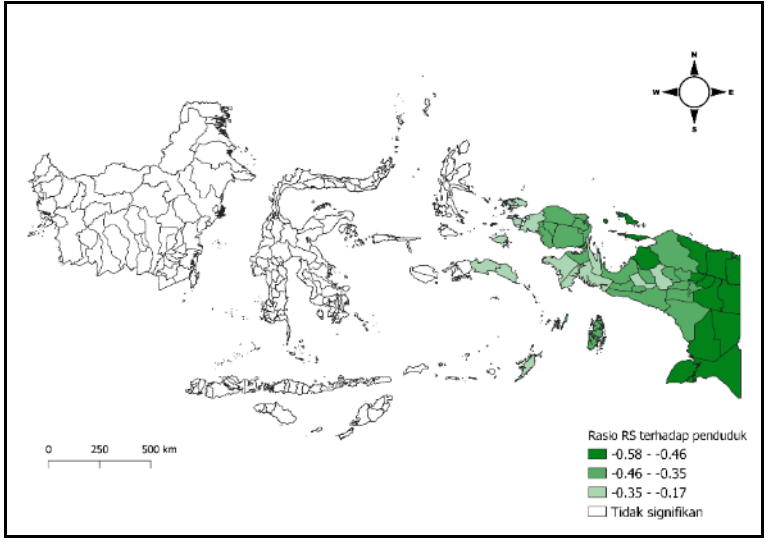

(a)

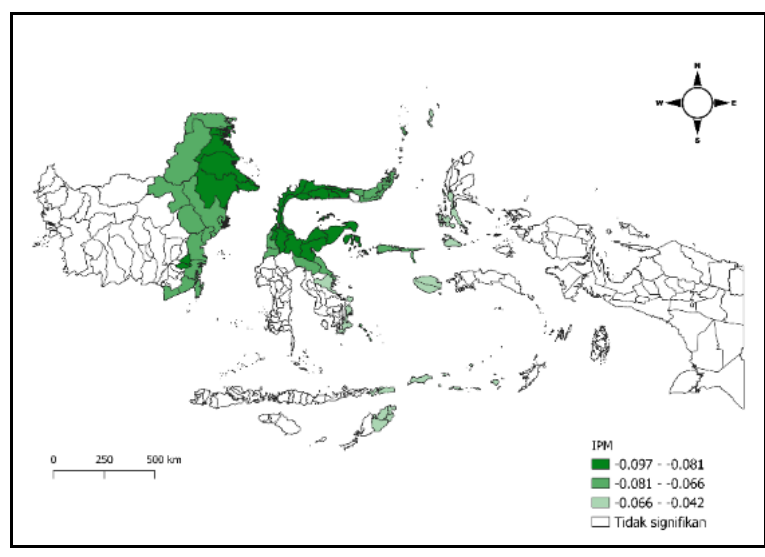

(b)

GAMBAR 3. Estimasi koefisien variabel lokal: (a) rasio rumah sakit terhadap penduduk

Pengaruh signifikan rasio rumah sakit terhadap penduduk pada GAMBAR 3a terjadi pada 48 kabupaten/kota di KTI. Secara umum, rasio rumah sakit hanya memiliki pengaruh signifikan negatif di Provinsi Papua, Papua Barat, dan beberapa kabupaten/kota di Provinsi Maluku. Pengaruh tersebut sejalan dengan WHO (2003) bahwa penduduk miskin rentan terhadap penyakit dan memiliki akses yang terbatas kepada perawatan kesehatan dan asuransi sosial. Ketika penduduk miskin sakit atau terluka, maka penduduk miskin tersebut dapat terjebak di dalam kemiskinan.

Selanjutnya, GAMBAR 3b memperlihatkan bahwa terdapat 107 kabupaten/kota yang signifikan dipengaruhi oleh variabel persentase desa dengan jalan mayoritas aspal. Pengaruh signifikan negatif tersebut terjadi di seluruh Pulau Kalimantan dan beberapa kabupaten/kota seperti di Provinsi Maluku dan Nusa Tenggara Timur. Pengaruh tersebut sejalan dengan penelitian oleh Salam et al. (2020) bahwa jalan dengan kondisi yang baik berpegaruh negatif terhadap kemiskinan karena dapat mempermudah akses transportasi, investasi, lapangan kerja.

Kemudian, GAMBAR 4 memperlihatkan bahwa variabel persentase desa tanpa sinyal internet memengaruhi AKM pada 133 kabupaten/kota di KTI. Pengaruh negatif signifikan variabel persentase desa tanpa sinyal internet terjadi di sebagian besar wilayah KTI, kecuali Pulau Kalimantan. Internet digunakan sebagai instrumen pembangunan di berbagai bidang. Internet dapat memperkuat interaksi sosial dan bisnis serta memberikan peluang dalam meningkatkan kesempatan kerja, meningkatkan derajat pendidikan dan pendapatan, sehingga dapat membantu memberantas kemiskinan (Rivera dan Mora, 2020).

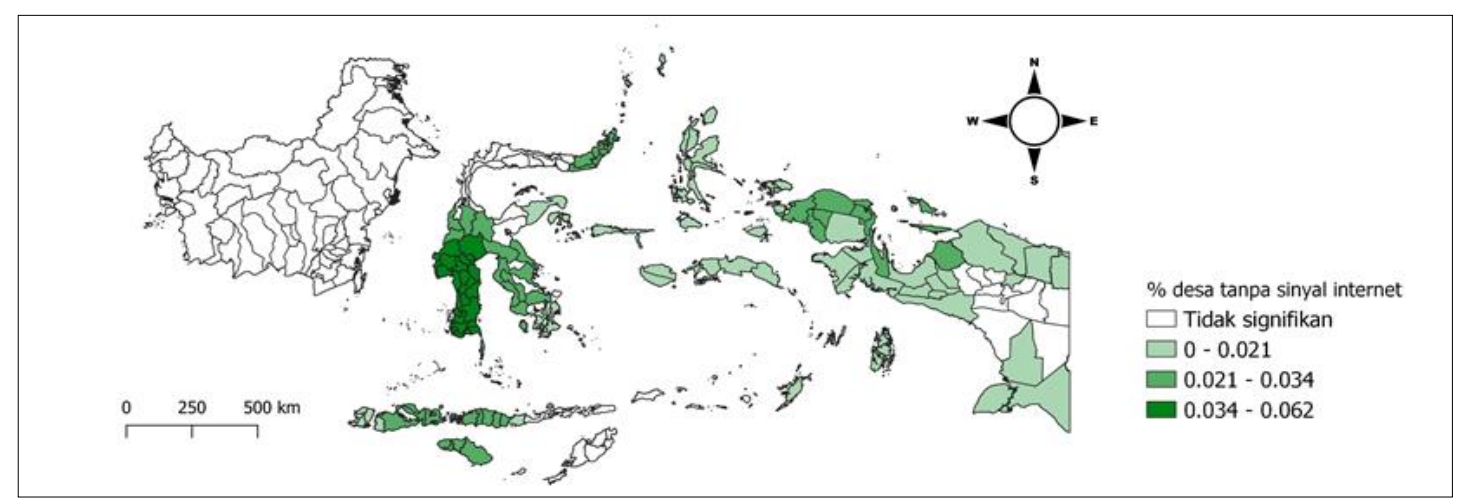

GAMBAR 4. Estimasi koefisien variabel lokal persentase desa tanpa sinyal internet 


\section{KESIMPULAN DAN SARAN}

Hasil pemodelan GWR menujukkan bahwa seluruh variabel independen yaitu rasio ketergantungan, IPM, rasio rumah sakit terhadap penduduk, persentase desa dengan jalan mayoritas aspal, dan persentase desa tanpa sinyal internet memiliki pengaruh signifikan dengan tingkat signifikansi 5 persen yang berbeda-beda terhadap kemiskinan multidimensi kabupaten/kota di KTI. Variabel persentase desa tanpa sinyal internet merupakan variabel yang paling banyak memengaruhi kemiskinan multidimensi kabupaten/kota di KTI secara signifikan yaitu signifikan pada 133 kabupaten/kota. Adapun saran yang dapat direkomendasikan adalah program kebijakan terkait pengentasan kemiskinan di KTI sebaiknya diterapkan dengan mempertimbangkan aspek spasial sehingga dapat berbeda-beda pada setiap cakupan wilayah.

\section{REFERENSI}

Andrietya, Achyarnis Lilik, Amin Pujiati, and Andryan Setyadharma. 2020. "Determinants of Poverty in Central Java Province 2013-2018." Journal of Economic Education 9(1):81-88.

Anselin, Luc. 1988. Spatial Econometrics: Methods and Models. 1st ed. Dordrecht: Kluwer Academic Publishers.

Badan Pusat Statistik. 2013. Penggunaan Metode Geographically Weighted Regression (GWR) Untuk Analisis Data Sosial Dan Ekonomi. Jakarta: BPS.

Fardilla, Shiffa, and Raja Masbar. 2020. "Analisis Pengaruh Infrastruktur Jalan, Listrik, Sekolah, Dan Terhadap Kemiskinan Di Aceh.” Jurnal Ilmiah Mahasiswa (JIM) 5(3):175-83.

Fotheringham, Stewart, Chris Brunsdon, and Martin Charlton. 2002. Geographically Weighted Regression: The Analysis of Spatially Varying Relationships. Wiley.

Harmes, Bambang Juanda, Ernan Rustiadi, and Baba Barus. 2017. "Pemetaan Efek Spasial Pada Data Kemiskinan Kota Bengkulu Spatial Effect Mapping for Poverty Data in Bengkulu City." Journal of Regional and Rural Development Planning Juni 1(2):192-201.

Kartasasmita, Ginandjar. 1996. Pembangunan Untuk Rakyat. Jakarta: PT. Pustaka Cidesindo.

Laderchi, Caterina Ruggeri, Ruhi Saith, and Frances Stewart. 2003. "Does It Matter That We Do Not Agree on the Definition of Poverty? A Comparison of Four Approaches." Oxford Development Studies 31(3):243-74.

Mora-Rivera, Jorge, and Fernando García-Mora. 2021. "Internet Access and Poverty Reduction: Evidence from Rural and Urban Mexico." Telecommunications Policy 45(2).

PRAKARSA. 2020. Indeks Kemiskinan Multidimensi Indonesia 2015-2018. Jakarta: Perkumpulan PRAKARSA.

Salam, Abdus, Devando Shasta Pratomo, and Putu Mahardika Adl Saputra. 2020. "Sosio-Economic Determinants Of Multidimensional Poverty In The Rural And Urban Areas Of East Java." International Journal Of Scientific \& Technology Research 9(4).

Sayifullah, and Ratu Tia Gandasari. 2016. "Pengaruh Indeks Pembangunan Manusia Dan Pengangguran Terhadap Kemiskinan Di Provinsi Banten.” Jurnal Ilmu Ekonomi 6(2):115-273.

Vijayakumar, Sinnathurai. 2013. "An Empirical Study on the Nexus of Poverty, GDP Growth, Dependency Ratio and Employment in Developing Countries." Journal of Competitiveness $5(2): 67-82$.

Widiyastuti, Inasari. 2015. "Analisis Runtun Waktu Dalam Pengujian Pengaruh TIK Terhadap Penurunan Laju Kemiskinan Di Indonesia.” IPTEK-KOM 17(1):19-30.

World Health Organization. 2003. DAC Guidelines and Reference Series: Poverty and Health. Paris: OECD. 